\title{
Social Class Inequalities in Educational Attainment: Measuring Social Class using Capitals, Assets and Resources
}

\author{
Roxanne Connelly, University of York \\ Vernon Gayle, University of Edinburgh \\ Chris Playford, University of Exeter
}

\section{Introduction}

The study of social class has been central to sociology since its foundations (Giddens, 1971). Research on social class has been one of the hallmarks of UK sociology since it burgeoned as an academic discipline after the Second World War (Pevalin and Rose, 2002). Historically, there has been a broad sociological consensus that social classes can generally be regarded as socio-economic groupings that divide the population into unequally rewarded categories (Crompton, 2008). Despite the centrality of social class within the sociological enterprise, the definitions and measurements are often muddled and frequently imprecise (see Breen and Rottman, 1995). A wide range of social class measures have been advocated and deployed in empirical research projects (for a review see Lambert and Bihagen, 2014).

Historically, occupations and the occupational structure were considered central to the sociological conception of social class (Blau and Duncan, 1967: 6-7). Indeed, there has been a long-standing recognition that in industrialised societies, occupations are the most powerful single indicator of levels of material reward, social standing and life chances (Parkin, 1971). The occupational information that is routinely provided in large-scale social surveys is therefore a key resource for operationalising measures of social class.

Several occupation-based social class measures can trace their genesis to the influential Erikson-Goldthorpe-Portocarero (EGP) schema (see Erikson et al., 1979). For example the official UK National Statistics Socio-economic Classification (NS-SEC) which is ubiquitous in British social research and official statistics (Rose and Pevalin, 2003; Rose et al., 2005). At the core of these schemes is the theoretical conception that employment relations in the labour market are central to the allocation of individuals into social class categories (Erikson and Goldthorpe, 1992). Individuals within a social class are theoretically understood as sharing a similar 'market situation' (e.g. levels of income, economic security, and chances for economic advancement), and 'work situation' (e.g. authority and control) (Goldthorpe, 1980). Following from this co-location, individuals within a social class are theorised as having similar lifestyles and comparable life chances (Rose and Pevalin, 2003).

More recently, Savage et al. (2013) have proposed an alternative theoretical basis for the measurement of social class, which is influenced by Bourdieusian rather than neo-Weberian theory. We refer to this as the Capitals, Assets and Resources (CAR) approach. Under this theoretical umbrella, occupations are not theorised as the central indicator of social class. By contrast, and following Bourdieu (1984), the concepts of economic capital (e.g. income and wealth), cultural capital (e.g. engagement with cultural goods and activities) and social capital (e.g. social contacts and networks) are theorised as playing a fundamental role in ascribing the individual's class position.

The CAR approach is a radical departure from the more orthodox occupation-based conception of social class but there have been important theoretical and methodological criticisms of the 
CAR-based approach to social class (see for example Mills, 2014; Mills, 2015; Payne, 2013; Bradley, 2014; Lui, 2015). Arguably however, a measure of social class should be empirically evaluated and should not be uncritically adopted either as a result of a theoretical standpoint, or by methodological fiat.

Savage (2016) makes an appeal for stratification researchers to modestly appreciate the benefits of both CAR and occupation-based social class measures. In response, the central goal of this paper is to evaluate the benefits of CAR and occupation-based measures of social class for studying the relationship between parental social class and educational outcomes. First we aim to assess how closely we can replicate the CAR-based social class measure reported in Savage et al. (2013).

Second, we aim to compare and contrast the CAR-based social class measure with the occupation-based National Statistics Socio-economic Classification, in an analysis of inequalities in school General Certificate of Secondary Education (GCSE) outcomes. The GCSE is the main qualification that pupils in England study for as they approach the end of compulsory education. The study of the relationship between parent's social class and their children's educational outcomes is ubiquitous in social stratification research (see Douglas, 1964; Lacey, 1970; Willis, 1977). Despite changes in the education system in the UK, children from less advantaged social classes (for example those with parents in routine, semi-routine and manual occupations) still have far less favourable educational outcomes (for example see Shavit and Blossfeld, 1991; Savage and Egerton, 1997; Goldthorpe and Jackson, 2008; Connolly, 2006; Strand, 2014).

\section{Data}

This paper capitalises on a new data resource which links data extracted from the National Pupil Database, an assemblage of administrative education data, to a large scale omnibus UK social survey, Understanding Society (the UK Household Longitudinal Study) (Department for Education et al., 2015). Understanding Society is a longitudinal survey which has followed the lives of individuals within households since 2009, and it subsumed the British Household Panel Study which began following household members in 1991 (Buck and McFall, 2011). Whilst GCSE qualifications are undertaken by pupils in England, Wales and Northern Ireland, the National Pupil Database only contains data for pupils registered in English state schools, therefore English state school pupils are the focus of this analysis ${ }^{1}$. Based on the availability of data on pupil's GCSE attainment and parental information we focus our analysis on young people who completed their GCSEs between school years 2009/10 and 2012/13.

\footnotetext{
${ }^{1}$ Only a small proportion of pupils, around 7\%, attend independent schools (Department for Education, 2019).
} 


\section{Aim 1: Replicating the CAR-based Social Class Measure}

The first stage of our analysis is an attempt to replicate the Savage et al. (2013) CAR measure using existing data from Understanding Society. Our analysis represents a genuine attempt to undertake an assay of Savage et al. (2013) with a source of high quality existing social survey data. The linked administrative data used in this analysis is treated securely and has to conform to standard principles of statistical disclosure control (Department for Education et al., 2015). This means that some numbers are not shown, where this has occurred it is indicated in the tables.

In our analysis we utilise data for both of the young person's parents where available. As many of the questions used to indicate the capitals, assets and resources are not asked in every wave of the survey we use measures taken over the first six waves of the survey data, however we do not use any observations taken when the young person is over 16 years of age. Savage et al. (2013) create scales of cultural, economic and social capital and use a latent class ${ }^{2}$ analysis to identify their seven new social classes. Savage et al. (2013) do not provide detail on how these scales were produced and standardised. Therefore, it is not possible for us to follow this strategy and we do not create scores from the categorical variables before entering these variables into a latent class analysis. Scaling manifest indicators, especially categorical indicators, prior to a latent class analysis is an unorthodox practice and potentially leads to the model reflecting the scaling of the manifest variables rather than reflecting the structure of differences between responses (Bauer et al., 2003).

\section{Cultural Capital Variables}

Bourdieu (1977) argues that cultural capital plays a major role in the reproduction of social inequalities through education. Bourdieu and Passeron (1990) argue that those young people who possess cultural capital will gain most from the education system due to their familiarity and competency in dealing with the dominant culture. Savage et al. (2013) use correspondence analysis to aide in the identification of elements of cultural capital, which are then used to create summated ratings scales of 'highbrow' and 'emerging' cultural capital (see Bennett et al., 2009).

The indicators used by Savage et al. (2013) to indicate 'highbrow' cultural capital are engagement with classical music, attending stately homes, museums, art galleries, jazz music, theatre and French restaurants. 'Emerging' cultural capital is indicated by measures of engagement with video games, social network sites, the internet, playing sport, watching sport, spending time with friends, going to the gym, going to gigs and preferences for rap and rock music.

In our analysis, we use variables that indicate whether either parent has engaged with a given cultural activity over the last twelve months. For 'highbrow' cultural capital we use measures of attendance at classical music performances, visits to a historic building, museum or gallery, going to a play / drama or pantomime, or a ballet performance. For 'emerging' cultural capital we use measures of belonging to a social media website, regularly using the internet, taking part in health, fitness, gym or conditioning activities, cycling for sport or recreation, taking part in racquet sports, or playing golf. We also include a further measure of attending a rock / pop

\footnotetext{
${ }^{2}$ Throughout the Savage et al. (2013) paper the analysis is described as a latent class analysis, however a footnote to the paper identifies that this is a latent profile analysis as the manifest variables used are all continuous.
} 
/ or jazz concert which combines music types which are defined as 'highbrow' (i.e. jazz) and 'emerging' (i.e. rock and pop) in the original analysis, but which are asked within a single question in the Understanding Society data. These variables are all binary. Descriptive statistics for these variables are shown in table 1.

\section{Economic Capital Variables}

Economic capital represents the command of economic resources (Bourdieu, 1986). In Savage et al. (2013) three indicators of economic capital are used, household income, household savings and house price. We use a continuous variable of household equivalised net monthly income, as well as a binary variable indicating whether the household own their home (including with a mortgage) or not. The Understanding Society data also include a measure of house price, however we needed to simplify our models due to convergence issues and this variable was removed. We do not include an explicit measure of household savings in our analysis, however the income variable we use also includes income from investments as well as labour income (see Fisher et al., 2019). Descriptive statistics for these variables are shown in table 1.

\section{Social Capital Variables}

Social capital represents the possession of a network of social connections that can be used to produce or reproduce inequality (Bourdieu, 1986). In Savage et al. (2013) respondents are given a list of 37 occupations and are asked to identity whether they know someone socially who does that kind of work. From this, they create the mean CAMSIS score of the respondent's social contacts. They also include an indicator of the number of social contacts reported from this list. CAMSIS is an occupation-based measure of relative social advantage (Stewart et al., 1980; Prandy and Lambert, 2003).

The Understanding Society data does not offer social capital measures that closely mirror those used in the original analysis. We have chosen to use the number of friends of the parent with the greatest number of friends, although this has the limitation that we do not know the level of advantage of this social network. We also include measures that indicate whether either parent is active in a trade union or a professional organisation. We specifically include measures of activity rather than membership in an attempt to identify parents who are likely to be involved in activities concerning social action, which may encompass working alongside a varied network of individuals. Descriptive statistics for these variables are shown in table 1. 
Table 1: Descriptive Statistics - Unweighted

\begin{tabular}{|c|c|c|c|}
\hline & Mean & $\begin{array}{l}\text { Std. } \\
\text { Dev. }\end{array}$ & $\mathbf{n}$ \\
\hline Equivalised net monthly household income & 1417.82 & 897.26 & 617 \\
\hline Parent's number of close friends & 5.38 & 4.35 & 617 \\
\hline \multirow[t]{2}{*}{ GCSE Points Score } & 45.02 & 20.21 & 617 \\
\hline & & $\%$ & $\mathbf{n}$ \\
\hline \multirow[t]{2}{*}{ Parents own their own home } & No & 22.85 & 141 \\
\hline & Yes & 77.15 & 476 \\
\hline \multirow[t]{2}{*}{ Parents active in trade union } & No & 94.17 & 581 \\
\hline & Yes & 5.83 & 36 \\
\hline \multirow[t]{2}{*}{ Parents active in professional organisation } & No & 88.49 & 546 \\
\hline & Yes & 11.51 & 71 \\
\hline \multirow[t]{2}{*}{ Either parent attended classical music performance } & No & 86.87 & 536 \\
\hline & Yes & 13.13 & 81 \\
\hline \multirow[t]{2}{*}{ Either parent visited historic building } & No & 55.11 & 340 \\
\hline & Yes & 44.89 & 277 \\
\hline \multirow[t]{2}{*}{ Either parent visited museum / gallery } & No & 47.97 & 296 \\
\hline & Yes & 52.03 & 321 \\
\hline \multirow[t]{2}{*}{ Either parent attended play / drama / pantomime } & No & 46.52 & 287 \\
\hline & Yes & 53.48 & 330 \\
\hline \multirow[t]{2}{*}{ Either parent attended ballet } & No & 94.33 & 582 \\
\hline & Yes & 5.67 & 35 \\
\hline \multirow[t]{2}{*}{ At least one parent uses social media } & No & 37.12 & 229 \\
\hline & Yes & 62.88 & 388 \\
\hline \multirow[t]{2}{*}{ At least one parent regularly uses the internet regularly } & No & 18.15 & 112 \\
\hline & Yes & 81.85 & 505 \\
\hline \multirow[t]{2}{*}{ Either parent participates in health / fitness / gym } & No & 53.81 & 332 \\
\hline & Yes & 46.19 & 285 \\
\hline \multirow[t]{2}{*}{ Either parent Rock / Pop / Jazz Concert } & No & 64.02 & 395 \\
\hline & Yes & 35.98 & 222 \\
\hline \multirow{2}{*}{ Either parent does cycling for recreation or sport } & No & 62.56 & 386 \\
\hline & Yes & 37.44 & 231 \\
\hline \multirow[t]{2}{*}{ Either parent plays racquet sports } & No & 80.06 & 494 \\
\hline & Yes & 19.94 & 123 \\
\hline \multirow[t]{2}{*}{ Either parent plays racquet golf } & No & 88.17 & 544 \\
\hline & Yes & 11.83 & 73 \\
\hline \multirow[t]{2}{*}{ Young Person's Sex } & Female & 52.51 & 324 \\
\hline & Male & 47.49 & 293 \\
\hline \multirow[t]{2}{*}{ Young Person's Ethnicity ${ }^{\dagger}$} & White & 80.55 & 497 \\
\hline & Non White & 19.45 & 120 \\
\hline \multirow[t]{4}{*}{ Academic Year } & $2009 / 2010$ & 3.57 & 22 \\
\hline & $2010 / 2011$ & 20.91 & 129 \\
\hline & $2011 / 2012$ & 37.44 & 231 \\
\hline & $2012 / 2013$ & 38.09 & 235 \\
\hline
\end{tabular}

Note: For the continuous variables, minimum and maximum values are not shown for statistical disclosure control purposes. ${ }^{\dagger}$ The ethnicity variable has been simplified in this table for statistical disclosure control purposes. 


\section{Latent Class Analysis}

We now estimate a latent class model containing the indicators of capitals, assets and resources described above. Latent class models relate a set of observed variables to a set of latent or unmeasured classes (McCutcheon, 1987). We include two continuous variables and 15 binary variables in total. As our model contains both continuous and categorical variables it would be best described as a latent class model of mixed observed variables. The Understanding Society data have a complex sample design. Our latent class models are estimated in Stata 16 using the -gsem- command, which does not currently support the analysis of complex samples (StataCorp, 2019). Our latent class analysis is therefore appropriately weighted, but does not fully adjust for the design of the sample. Due to the select nature of this sample (i.e. parents in UKHLS households which include young people completing their GCSEs between school years 2009/10 and 2012/13) and the variables required over multiple waves of the survey data, our final sample size is relatively small $(\mathrm{n}=617)$.

Table 2 reports the model fit statistics for a series of latent class models. The six class model is an improvement on the five class model, with a lower AIC and higher entropy. The six class model is preferred over the seven class model as it has a lower BIC and a higher entropy. However, we note that there is very little difference between the model fit statistics of the models and there is certainly no definitive class solution. Savage et al. (2013) state that the seven class model they discuss was selected as it minimised BIC, however technical details in later sources note that the eight class solution minimised BIC (Savage et al., 2015). This uncertainty is important to note as latent class analysis rarely identifies a definitive solution (McCutcheon, 1987).

Table 2: Model of Fit Statistics of the Latent Class Models

\begin{tabular}{lrrrrrr}
\hline Model & $\mathbf{n}$ & ll(model) & df & AIC & BIC & Entropy \\
\hline Two Class & 616 & -12000.03 & 37 & 24074.06 & 24237.72 & 0.81 \\
Three Class & 616 & -11927.50 & 54 & 23962.99 & 24201.85 & 0.83 \\
Four Class & 616 & -11834.21 & 68 & 23804.42 & 24105.20 & 0.86 \\
Five Class & 616 & -11739.05 & 85 & 23648.10 & 24024.08 & 0.94 \\
Six Class & 616 & -11693.06 & 103 & 23592.12 & 24047.71 & 0.96 \\
Seven Class & 616 & -11670.82 & 120 & 23581.65 & 24112.43 & 0.95 \\
Eight Class & 616 & -11659.57 & 135 & 23589.13 & 24186.27 & 0.94 \\
Nine Class & 616 & -11605.72 & 142 & 23495.43 & 24123.54 & 0.93 \\
\hline
\end{tabular}

Note: The sample size reduces by one case in the weighted analyses as one sample member has a weight of zero (unweighted $n=617$ ).

The results of the six category latent class model are reported in table 3 . Respondents were allocated to the latent classes through modal assignment ${ }^{3}$. The 'elite' class and the 'socially engaged middle class' contain only a very small number people. The percent of parents in our sample allocated to these classes cannot be presented because of statistical disclosure control. The 'culturally engaged middle class' is also a very small class comprising only 11 per cent of families. There are three larger classes, the 'established middle class' comprising 31 per cent

\footnotetext{
${ }^{3}$ In modal assignment each unit is assigned to the latent class with the largest (modal) estimated probability of membership. For a fuller discussion of methods of assignment, see Heron et al. (2015); Nylund et al. (2007); Bakk et al. (2013).
} 
of families, the 'traditional working class' comprising 35 per cent of families, and the 'precariat' comprising 19 per cent of families.

We have ascribed labels to the latent classes based on the profile of responses to the manifest variables. We began with the labels ascribed in Savage et al. (2013), but then made adjustments as the classes we have observed do not replicate those identified in the original analysis. The 'elite' are clearly the most economically advantaged group of families. In relation to economic capital, this group has by far the highest average income and home ownership. This is the characteristic of this group which stands out in comparison to the other social classes. They have relatively high levels of social capital and relatively high levels of both 'highbrow' and 'emerging' cultural capital, although not always the highest.

We have then ascribed the next three classes as being 'middle class'. We have the 'established' middle class, the 'socially engaged' middle class and the 'culturally engaged' middle class. These three groups are all relatively high earning families with a high probability of home ownership. The 'established' middle class are not the highest earning of these three but they are the most likely to own their own home. They have average social capital, and relatively high engagement with 'highbrow' and 'emerging' cultural capital. The 'socially active' middle class are distinguished by their very high number of friends. The 'culturally engaged' middle class are distinguished by their high likelihood of participation in both 'highbrow' and 'emerging' cultural capital. This group has particularly high engagement with activities aligned with 'emerging' cultural capital such as social media use, and participation in sports-based activities.

The final two social classes are ascribed the titles of the 'traditional working class' and the 'precariat'. Although we note that our precariat does appear to be more advantaged than the precariat described by Savage et al. (2013). This might be due to our focus on parents and not the population as a whole. The 'traditional working class' are the lowest earning group of families, however they are still relatively likely to own their own home. They have low social capital, and low levels of engagement with 'highbrow' and 'emerging' cultural capital. However, this group do have a high propensity to use social media and the internet. The 'precariat' are the second lowest earning group of families, and are the least likely to own their own home. They have very low levels of social capital, and low levels of engagement with 'highbrow' and 'emerging' cultural capital.

To investigate how our new CAR measure compares to the widely used National Statistics Socio-economic Classification we have also operationalised this measure using the Understanding Society data. Here we utilise data from the parents in the household when the young person is age 14, in line with standard practice. Table 4 shows the association between the three big CAR classes described above and the NS-SEC categories. We can see that these two social class measures are strongly associated. Most of the 'established middle class' (67 per cent) are allocated to the most advantaged NS-SEC classes (1.1 to 2), the 'traditional working class' are allocated towards the middle and lower end of the NS-SEC schema, and 49 per cent of the 'precariat' are allocated to the least advantaged NS-SEC classes (6 and 7). 
Table 3: Prior Probabilities for the Six Latent Class Solution.

\begin{tabular}{|c|c|c|c|c|c|c|}
\hline Ascribed Label & 'Elite' & $\begin{array}{c}\text { 'The Established } \\
\text { Middle Class' }\end{array}$ & $\begin{array}{r}\text { 'The Socially } \\
\text { Engaged } \\
\text { Middle Class' }\end{array}$ & $\begin{array}{r}\text { 'The Culturally } \\
\text { Engaged Middle } \\
\text { Class' }\end{array}$ & $\begin{array}{l}\text { 'The Traditional } \\
\text { Working Class' }\end{array}$ & 'The Precariat' \\
\hline \% Allocated to Latent Class & - & 31 & - & 11 & 35 & 19 \\
\hline \multicolumn{7}{|l|}{ Prior Probabilities } \\
\hline \multicolumn{7}{|l|}{ Economic Capital } \\
\hline Equivalised Net Monthly & 7298.64 & 1559.42 & 1568.76 & 1494.50 & 1232.39 & 1348.61 \\
\hline \multicolumn{7}{|l|}{ Household Income (mean) } \\
\hline Own Home & 1.00 & 0.91 & 0.86 & 0.95 & 0.75 & 0.52 \\
\hline \multicolumn{7}{|l|}{ Social Capital } \\
\hline Number of Friends (mean) & 6.14 & 5.16 & 25.03 & 7.45 & 4.91 & 3.96 \\
\hline Active in Trade Union & 0.15 & 0.09 & 0.05 & 0.09 & 0.02 & 0.06 \\
\hline Active in Professional Organisation & 0.68 & 0.16 & 0.37 & 0.37 & 0.04 & 0.00 \\
\hline \multicolumn{7}{|l|}{ Highbrow Cultural Capital } \\
\hline Classical Music Concerts & 0.57 & 0.23 & 0.23 & 0.34 & 0.03 & 0.00 \\
\hline Historic Buildings & 0.42 & 0.86 & 0.61 & 0.95 & 0.12 & 0.13 \\
\hline Museums / Galleries & 0.85 & 0.84 & 0.78 & 0.98 & 0.21 & 0.29 \\
\hline Plays/Theatre/Pantomime & 1.00 & 0.88 & 0.80 & 0.77 & 0.33 & 0.20 \\
\hline Ballet Performance & 0.14 & 0.13 & 0.23 & 0.14 & 0.00 & 0.00 \\
\hline \multicolumn{7}{|l|}{ Emerging Cultural Capital } \\
\hline Social Media & 0.58 & 0.64 & 0.42 & 0.88 & 0.83 & 0.28 \\
\hline Regularly use the Internet & 1.00 & 0.92 & 1.00 & 1.00 & 1.00 & 0.24 \\
\hline Gym/Fitness Classes & 0.60 & 0.45 & 0.55 & 0.93 & 0.44 & 0.22 \\
\hline Rock/Pop/Jazz Concert & 0.82 & 0.59 & 0.58 & 0.69 & 0.22 & 0.10 \\
\hline Cycle & 0.42 & 0.46 & 0.43 & 0.99 & 0.28 & 0.12 \\
\hline Racquet Sports & 0.13 & 0.24 & 0.66 & 0.66 & 0.09 & 0.06 \\
\hline Golf & 0.27 & 0.19 & 0.19 & 0.28 & 0.07 & 0.03 \\
\hline
\end{tabular}

Note: - indicates that the values in the cell have been suppressed for statistical disclosure control purposes. $\mathrm{n}=616$. The sample size reduces by one case in the weighted analyses as one sample member has a weight of zero (unweighted $n=617$ ). 
Table 4: Association between parental NS-SEC and the CAR-based parental social class measure (Unweighted).

\begin{tabular}{|c|c|c|c|c|c|c|c|c|c|}
\hline & & & & $\begin{array}{r}\text { NS-S } \\
\text { lweight }\end{array}$ & $\begin{array}{l}\mathrm{EC} \\
\mathrm{d} n(\%)\end{array}$ & & & & \\
\hline & 1.1 & 1.2 & 2 & 3 & 4 & 5 & 6 & 7 & Total \\
\hline $\begin{array}{l}\text { The } \\
\text { Established } \\
\text { Middle } \\
\text { Class }\end{array}$ & $\begin{array}{r}27 \\
(14 \%)\end{array}$ & $\begin{array}{r}33 \\
(17 \%)\end{array}$ & $\begin{array}{r}69 \\
(36 \%)\end{array}$ & $\begin{array}{r}30 \\
(15 \%)\end{array}$ & - & - & - & - & $\begin{array}{r}194 \\
(100 \%)\end{array}$ \\
\hline $\begin{array}{l}\text { The } \\
\text { Traditional } \\
\text { Working } \\
\text { Class }\end{array}$ & - & - & $\begin{array}{r}66 \\
(30 \%)\end{array}$ & $\begin{array}{r}33 \\
(15 \%)\end{array}$ & $\begin{array}{r}27 \\
(12 \%)\end{array}$ & $\begin{array}{r}15 \\
(7 \%)\end{array}$ & $\begin{array}{r}42 \\
(19 \%)\end{array}$ & - & $\begin{array}{r}219 \\
(100 \%)\end{array}$ \\
\hline $\begin{array}{l}\text { The } \\
\text { Precariat }\end{array}$ & - & - & $\begin{array}{r}14 \\
(12 \%)\end{array}$ & $\begin{array}{r}12 \\
(10 \%)\end{array}$ & $\begin{array}{r}19 \\
(16 \%)\end{array}$ & $\begin{array}{r}12 \\
(10 \%)\end{array}$ & $\begin{array}{r}37 \\
(31 \%)\end{array}$ & $\begin{array}{r}22 \\
(18 \%)\end{array}$ & $\begin{array}{r}120 \\
(100 \%)\end{array}$ \\
\hline
\end{tabular}

Note: - indicates that the values in the cell have been suppressed for statistical disclosure control purposes.

$$
\begin{array}{r}
\text { Pearson } \operatorname{chi}^{2}(35)=195.78, \mathrm{p}<0.001 \\
\text { Cramer's V }=0.25, \mathrm{n}=617
\end{array}
$$

Figure 1: Graph of quasi-variance comparison estimates for parental NS-SEC.

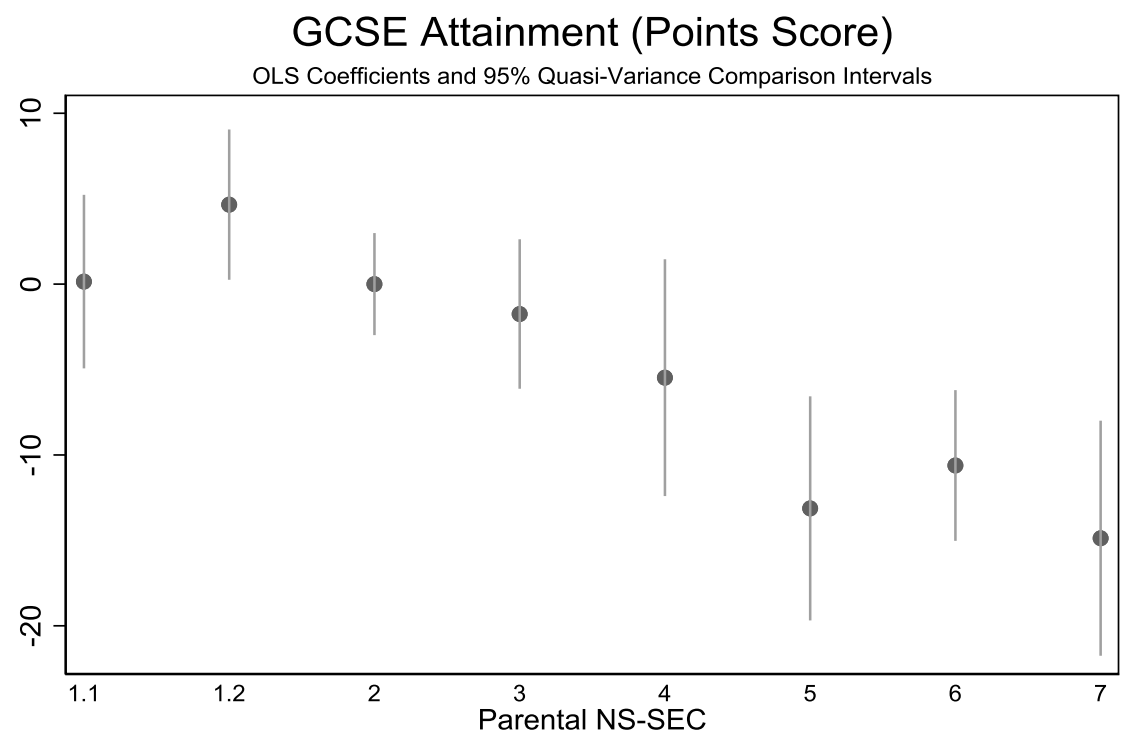

Note: Model also contains academic year, sex, ethnicity and parental education. R-Squared = $0.24, \mathrm{n}=616$. The sample size reduces by one case in the weighted analyses as one sample member has a weight of zero (unweighted $n=617$ ). 
Figure 2: Quasi-variance comparison estimates for parental CAR social class.

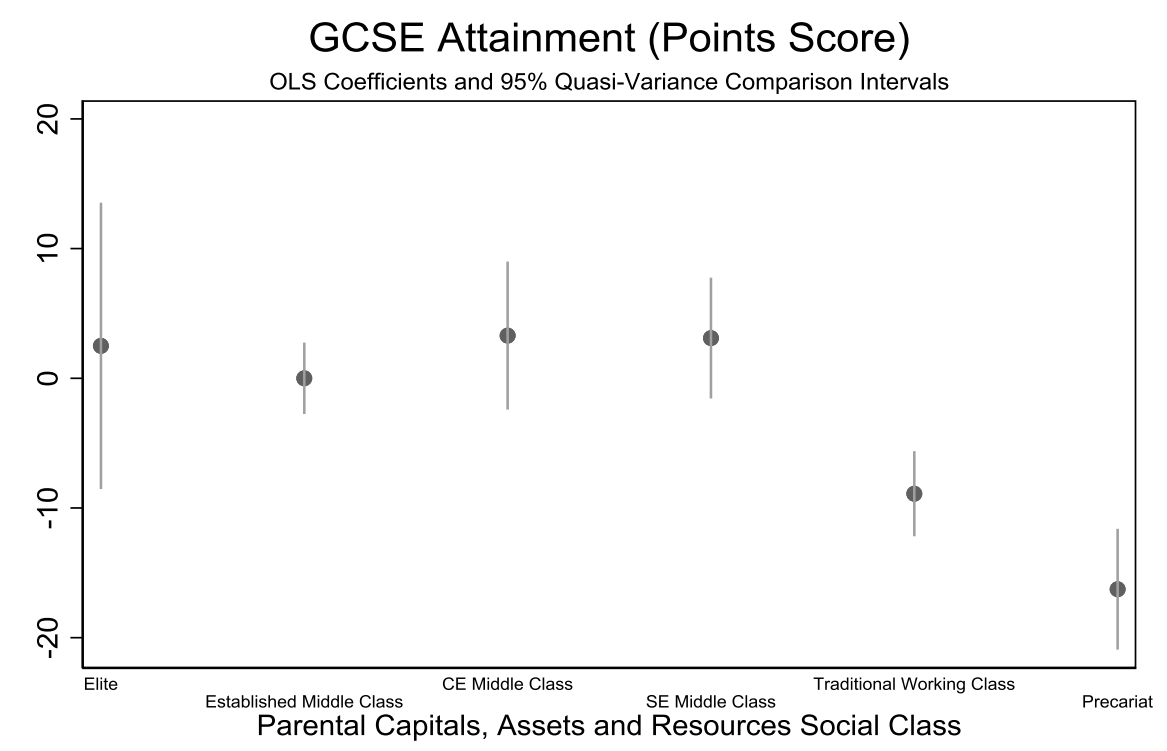

Note: Model also contains academic year, sex, ethnicity and parental education. R-Squared = $0.26, \mathrm{n}=616$. The sample size reduces by one case in the weighted analyses as one sample member has a weight of zero (unweighted $n=617$ ).

\section{Aim 2: Compare and Contrast the CAR Measure and NS-SEC in an Analysis of GCSE Outcomes}

We now apply the CAR measure described above in an analysis of GCSE attainment. GCSE subjects are assessed separately, and a subject-specific GCSE is awarded. Each GCSE subject is awarded a grade, historically the highest being grade A and the lowest grade G. From 1994 a higher grade of $\mathrm{A}^{*}$ was introduced (Yang and Woodhouse, 2001). Because GCSEs are taken as diet of many subjects and each subject is awarded an alphabetical grade there is no obvious single, or agreed, measure of overall school GCSE attainment. Following Playford and Gayle (2016), we calculated a measure of GCSE attainment based on allocating 7 points for an $A^{*} / A, 6$ points for a $B, 5$ points for a $C, 4$ points for a $D, 3$ points for an $E, 2$ points for a $\mathrm{F}$ and 1 point for a G. Previous analyses of school GCSE outcomes indicate that in addition to parental social class, a pupil's gender, ethnicity and their parent's level of education are also important, these variables are therefore also included in the models (Drew, 1995; Rothon, 2007; Strand, 2014). Descriptive statistics for GCSE points score, gender, ethnicity and social class are shown in table 1.

We estimate two linear regression models, one containing the new CAR-based measure and one containing NS-SEC. Both models are weighted and adjust for the complex sample design of Understanding Society. The full regression results are shown in the online supplement. Figure 1 shows the coefficient for the CAR-based social class measure with $95 \%$ quasivariance comparison intervals, and figure 2 shows the coefficient for the NS-SEC measure of parental social class with $95 \%$ quasi-variance comparison intervals.

The analysis using NS-SEC shows the familiar social class gradient (Demack et al., 2000). The model that contains the CAR-based measure offers only a marginal increase in explanatory power. The substantive pattern shown in the model containing the CAR-based measure does not provide any further insights regarding the association between parental social class and 
filial educational attainment. The main pattern highlighted by the CAR-based measure is a divide between the 'precariat' and the 'traditional working class', and the other class categories. It is also important to note that three of the CAR-based classes contain a very small number of participants and therefore have very wide comparison intervals.

\section{Conclusion}

The Bourdieusian theoretical foundation of the CAR approach represents a clear departure from orthodox neo-Weberian occupation-based social class measures such as the National Statistics Socio-economic Classification. Through an empirical example of educational inequalities, we have responded to the appeal made in Savage (2016) for researchers to appreciate the benefits of these two approaches. We now reflect on the issues that have emerged from this comparative work.

The first aim of the work was to assess how closely we could replicate the CAR-based social class measure reported in Savage et al. (2013). The overall finding is that it was not possible to recover the seven social classes reported in Savage et al. (2013). The latent class analysis of Understanding Society data recovered six classes, three of which contained only a very small number of sample members. The characteristics of these classes were very different in nature to the classes described in Savage et al. (2013). This may be because we have examined the parents of young people completing their GCSEs and not the wider UK population, but a requirement of a social class measure should be some degree of stability to allow for the examination of class-based inequalities in different scenarios.

The second aim of the work was to compare and contrast the CAR-based social class measure with the occupation-based National Statistics Socio-economic Classification, in an analysis of inequalities in school GCSE outcomes. Both the CAR-based social class measure and NS-SEC illustrate a social class gradient. Pupils with parents in more advantaged social classes, on average, have better school GCSE outcomes.

A striking feature is the overlap between the CAR measure and NS-SEC. The 'established middle class' largely comprise the higher managerial, administrative and professional occupations in NS-SEC. By contrast there are few parents in higher managerial, administrative and professional occupations in the 'traditional working class'. The 'precariat' largely comprises parents in semi-routine and routine occupations, and very few are in higher managerial, administrative and professional occupations. This degree of overlap is surprising. It would be reasonable to assume, a priori, that a social class measure based on levels of social, economic and cultural capital would not line up as neatly with an orthodox occupation-based measure with a neo-Weberian genesis.

We now reflect on the issues that have emerged from this comparative work. First, the study of population level social inequalities requires access to large-scale data resources. In practice few existing social surveys collect appropriate (manifest) variables suitable for measuring social, economic and cultural capital. The empirical work presented above unambiguously demonstrates that even in a household panel study, which is expressly designed to support a broad range of analyses, the full range of manifest indicators that Savage et al. (2013) identify as being required to construct the CAR social class measure are not available. 
When analysing datasets that do not contain all of the measures proposed by Savage et al. (2013) researchers will have to make choices about alternative operationalisations (e.g. using substitute measures). This ultimately hangs a question mark over the comparability of social class effects in different studies where alternative operationalisations of a CAR-based social class measure have been used. This issue may be especially stark when comparing social class effects over time.

An esoteric, but none the less consequential, technical aspect of a latent variable approach is that despite the versatility of these models in practice, deciding on the number of latent categories is a partially unresolved issue. There is no single commonly accepted statistical indicator for determining the number of latent categories (Nylund et al., 2007). It is imperative therefore to provide a range of formal measures that indicate the 'goodness of fit' of the modelling solution. Regrettably, such information is absent in Savage et al. (2013). Furthermore, whilst Savage et al. (2013) present their seven class solution as definitive, technical details indicate that eight classes could have been selected (Savage et al., 2015). Therefore, it is not possible to assess the propriety of the seven latent class model presented in Savage et al. (2013), or to evaluate alternative model solutions.

A further related technical issue is the assignment of individuals to latent categories. Here we have used 'modal' assignment which is a common method (see Bartholomew et al., 2008). Recently, technical discussions have emerged regarding alternative methods of assignment (see Vermunt 2010, Bakk, Tekle, and Vermunt 2013, Asparouhov and Muthén 2014, Heron et al. 2015). Once again we argue that it is imperative in the proposal of a measure developed using latent class models to provide clear information on methods of allocation in order for the measure to be correctly reproduced.

In conclusion, the results presented in this paper provide little support for the argument that CAR-based social class measures offer new insights into social class inequalities in school GCSE outcomes. Although it is important to recognise the important insights that studies of cultural engagement can bring to the study of social class inequalities in GCSE attainment (Sullivan, 2001) and the field of social stratification more generally (Chan, 2019). It is possible that further detailed analyses with bespoke data might have the power to highlight new insights offered by CAR-based social class measures, over and above, or in addition to more traditional social class measures. For routine analyses of class-based inequalities with existing social survey and administrative data sets we have shown that the use of CAR-based social class measures is problematic. 


\section{References}

Bakk Z, Tekle FB and Vermunt JK. (2013) Estimating the association between latent class membership and external variables using bias-adjusted three-step approaches. Sociological methodology 43: 272311.

Bartholomew DJ, Steele F, Moustaki I, et al. (2008) Analysis of Multivariate Social Science Data, Boca Raton, FL: CRC Press.

Bauer DJ, Borkenau P, Garner M, et al. (2003) The Scaling of Latent and Observed Variables in StateTrait Models. Measurement: Interdisciplinary Research and Perspectives 1: 207-231.

Bennett T, Savage M, Silva EB, et al. (2009) Culture, Class, Distinction, London: Routledge.

Bourdieu P. (1977) Cultural Reproduction and Social Reproduction. In: Karabel J and Halsey AH (eds) Power and Ideology in Education. Oxford: Oxford University Press, 487-510.

Bourdieu P. (1984) Distinction, London: Routledge.

Bourdieu P. (1986) The Forms of Capital. In: Richardson J (ed) Handbook of Theory and Research for the Sociology of Education. New York: Greenwood.

Bourdieu P and Passeron J-C. (1990) Reproduction in education, society and culture, London: Sage.

Bradley H. (2014) Class descriptors or class relations? Thoughts towards a critique of Savage et al. Sociology 48: 429-436.

Breen R and Rottman D. (1995) Class analysis and class theory. Sociology 29: 453-473.

Buck N and McFall S. (2011) Understanding Society: design overview. Longitudinal and Life Course Studies 3: 5-17.

Chan TW. (2019) Understanding cultural omnivores: social and political attitudes. The British journal of sociology 70: 784-806.

Connolly P. (2006) The effects of social class and ethnicity on gender differences in GCSE attainment: a secondary analysis of the Youth Cohort Study of England and Wales 1997-2001. British Educational Research Journal 32: 3-21.

Crompton R. (2008) Class and Stratification, Cambridge: Polity Press.

Demack S, Drew D and Grimsley M. (2000) Minding the Gap: Ethnic, gender and social class differences in attainment at 16, 1988- 95. Race Ethnicity and Education 3: 117-143.

Department for Education. (2019) Schools, Pupils and Their Characteristics, January 2019, London: Department for Education.

Department for Education, Univesity of Essex and Institute for Social and Economic Research. (2015) Understanding Society: Wave 1, 2009-2011: Linked National Pupil Database: Secure Access. [data collection]. 2nd Edition. UK Data Service. SN: 7642, http://doi.org/10.5255/UKDA-SN-7642-2.

Douglas JWB. (1964) The Home and the School: A study of ability and attainment in the primary school, London: MacGibbon and Kee.

Drew D. (1995) 'Race', Education and Work: The Statistics of Inequality, Aldershot: Avebury. 
Erikson R, Goldthorpe J and Portocarero L. (1979) Intergenerational Class Mobility in Three Western Societies: England, France, and Sweden. British Journal of Sociology 30: 415-441.

Erikson R and Goldthorpe JH. (1992) The Constant Flux: A Study of Class Mobility in Industrial Societies, Oxford: Clarendon Press.

Fisher P, Fumagalli L, Buck N, et al. (2019) Understanding Society and its income data. Colchester: Understanding Society at the Institute for Social and Economic Research.

Giddens A. (1971) Capitalism and modern social theory: An analysis of the writings of Marx, Durkheim and Max Weber: Cambridge University Press.

Goldthorpe J. (1980) Social Mobility and Class Structure in Modern Britain, Oxford: Clarendon.

Goldthorpe J and Jackson M. (2008) Problems of an Education-Based Meritocracy. In: Lareau A and Conley D (eds) Social Class: How Does it Work? London: Russell Sage.

Heron JE, Croudace TJ, Barker ED, et al. (2015) A comparison of approaches for assessing covariate effects in latent class analysis. Longitudinal and Life Course Studies 6: 420-434.

Lacey C. (1970) Hightown Grammar, Manchester: Manchester University Press.

Lambert PS and Bihagen E. (2014) Using occupation-based social classifications. Work, employment and society 28: 481-494.

Lui T-1. (2015) GBCS: an answer in search of a question. The Sociological Review 63: 480-492.

McCutcheon AL. (1987) Latent Class Analysis, London: Sage.

Mills C. (2014) The great British class fiasco: A comment on Savage et al. Sociology 48: 437-444.

Mills C. (2015) The Great British class survey: Requiescat in pace. The Sociological Review 63: 393399.

Nylund KL, Asparouhov T and Muthén BO. (2007) Deciding on the number of classes in latent class analysis and growth mixture modeling: A Monte Carlo simulation study. Structural equation modeling: A multidisciplinary Journal 14: 535-569.

Payne G. (2013) Models of contemporary social class: The Great British class survey. Methodological Innovations Online 8: 3-17.

Pevalin D and Rose D. (2002) The National Statistics Socio-economic Classification: unifying official and sociological approaches to the conceptualisation and measurement of social class in the United Kingdom. Sociétés contemporaines: 75-106.

Playford CJ and Gayle V. (2016) The concealed middle? An exploration of ordinary young people and school GCSE subject area attainment. Journal of Youth Studies 19: 149-168.

Prandy K and Lambert P. (2003) Marriage, social distance and the social space: an alternative derivation and validation of the Cambridge Scale. Sociology 37: 397-411.

Rose D and Pevalin DJ. (2003) The NS-SEC Explained. In: Rose D and Pevalin DJ (eds) A Researcher's Guide to the National Statistics Socio-economic Classification. London: Sage, 28-43.

Rose D, Pevalin DJ and O'Reilly K. (2005) The National Statistics Socio-economic Classification: origins, development and use: Palgrave Macmillan Basingstoke. 
Rothon C. (2007) Can achievement differentials be explained by social class alone? An examination of minority ethnic educational performance in England and Wales at the end of compulsory schooling. Ethnicities 7: 306-322.

Savage M. (2016) End class wars. Nature News 537: 475.

Savage M, Devine F, Cunningham N, et al. (2013) A new model of social class: Findings from the BBC's Great British Class Survey Experiment. Sociology.

Savage M, Devine F, Cunningham N, et al. (2015) GBCS and GfK Methodology and Technical Notes. Colchester: UK Data Service.

Savage M and Egerton M. (1997) Social Mobility, Individual Ability and the Inheritance of Class Inequality. Sociology 31: 645-672.

Shavit Y and Blossfeld H. (1991) Persistent Inequality: Changing Educational Attainment in Thirteen Countries, Boulder, Colorado: Westview Press.

StataCorp. (2019) Stata Structural Equation Modeling Reference Manual Release 16, College Station, TX: StataCorp.

Stewart A, Prandy K and Blackburn RM. (1980) Social stratification and occupations, New York: Holmes and Meier Publishers Inc.

Strand S. (2014) Ethnicity, gender, social class and achievement gaps at age 16: Intersectionality and 'Getting it' for the white working class. Research Papers in Education 29: 131-171.

Sullivan A. (2001) Cultural capital and educational attainment. Sociology 35: 893-912.

Willis P. (1977) Learning to Labour: How working class kids get working class jobs, London: Saxon House.

Yang M and Woodhouse G. (2001) Progress from GCSE to A and AS level: institutional and gender differences, and trends over time. British Educational Research Journal 27: 245-267. 